\title{
Gender differences in medical students' motives and career choice
}

Phil JM Heiligers ${ }^{1,2^{*}}$

\begin{abstract}
Background: The main subject is the influence of gender and the stage of life on the choice of specialty in medical education. In particular we looked at the influence of intrinsic and external motives on this relationship. The choice of specialty was divided into two moments: the choice between medical specialties and general practice; and the preference within medical specialties. In earlier studies the topic of motivation was explored, mostly related to gender. In this study stage of life in terms of living with a partner -or not- and stage of education was added.

Methods: A questionnaire concerning career preferences was used. The online questionnaire was sent to all student members of the KNMG (Royal Dutch Medical Association). 58\% of these students responded ( $N=2397)$. Only 1478 responses could be used for analyses (36\%). For stipulating the motives that played a role, principal components factor analysis has been carried out. For testing the mediation effect a set of regression analyses was performed: logistic regressions and multiple regressions.

Results: Although basic findings about gender differences in motivations for preferred careers are consistent with earlier research, we found that whether or not living with a partner is determinant for differences in profession-related motives and external motives (lifestyle and social situation). Furthermore living with a partner is not a specific female argument anymore, since no interactions are found between gender and living with a partner. Another issue is that motives are mediating the relationship between, living with a partner, and the choice of GP or medical specialty. For more clarity in the mediating effect of motives a longitudinal study is needed to find out about motives and changing circumstances.

Conclusions: The present study provides a contribution to the knowledge of career aspirations of medical students, especially the impact of motivation. Gender and living with a partner influence both choices, but they are not interacting, so living with a partner is similarly important for male and female students in choosing their preferences. Moreover, external and intrinsic motives mediate this relationship to a greater of lesser degree. First stage students are influenced by life-style and intrinsic motives in their choice of general practice. For second stage students, the results show influences of life-style motives next to profession-related motives on both moments of choice.
\end{abstract}

\section{Background}

Insight into the career choice of medical students has become a real issue as the student population is changing towards a majority of female students. The consequences of this increasingly female student population are not only being studied in the Netherlands, where this

\footnotetext{
* Correspondence: p.heiligers@nivel.nl

${ }^{1}$ NIVEL - Netherlands institute for health services research, PO Box 15683500 BN, Utrecht, The Netherlands

${ }^{2}$ Utrecht University, Faculty of Social sciences, PO Box 80.1403508 TC, Utrecht, the Netherlands
}

study was performed [1-3] but also in other countries [4-7]. The focus of the current study is to provide more insight into the impact of gender and, the stage in the student's life, on his or her preferences for a medical specialty. In addition, this study examines the influence of the gender and the stage of life on the motives that direct a student's career choices. We investigate the effect of external and intrinsic motives. These motives are expected to mediate the relationship between gender and the stage of life on the one hand, and future specialty on the other. 
Earlier studies on this topic have shown that the choice of specialty is related to gender. Male students opt for technical and instrumental oriented specialties and female students are more relationship oriented [8]. For example, male students more often choose surgery as a specialism, whereas female students tend to prefer to be a general practitioner. Again, this phenomenon was found both in the Netherlands [3,8-10] as well as in other countries [6,11-14].

Next to gender, the influence of students' stage of life is an important issue. Most students in our study are young, and may therefore be less likely to have a permanent partner. However, we expect that having a partner will have some impact on the choices for the future.

To some extent the ideas of the partner and the perspectives of balancing work and family will influence choices in specialties and might also influence the importance of several motivating aspects for the choice of specialty [1].

The main question in this study is to what extent are gender and the stage of life related to the choice of specialty and how intrinsic and external motives influence this relationship.

\section{Theoretical background}

In this study we focus on several perspectives that in earlier studies have been indicated as important contributions to explain a career choice. Our effort is to explain the relationship between these perspectives: the gender perspective, the perspective of the stage of life and the motivational perspective, in the decision of students to choose a particular career.

\section{Gender perspective}

Gender refers to aspects of sex related to behaviour and identity, which go beyond biological differences [15]. Although the participation of women in the labour market has increased, segregation can still be found between male and female professions or specialties. This segregation is mostly in favour of the professions or specialties which are typically male $[16,17]$. Expectations based on these patterns influence individual career choices of men and women, which is also the case for individual medical students and their expectations $[3,9,18,19]$. In several studies it was found that men, more often than women, choose the surgical specialties [3,6,9-14]. Van der Velden et. al. [20] found that in spite of the fact that women cover more than half of the Dutch medical student population; only $13 \%$ of all working surgery specialists are female. In other specialties $30 \%$ of all specialists are female, on average, with exceptions for gynaecology (40\%) and paediatrics (53\%), which are traditionally associated with the reproductive gender role of woman $[10,21]$.
From the gender perspective, we expect that male medical students are, more than female students, focused on specialties with technical and instrumental characteristics. Female students, more than men, will focus on specialties with opportunities for relational aspects.

\section{The stage of life perspective}

Next to gender, the stage of life is related to the choice of specialty [22]. Changes and transitions between the stages of life, such as marriage (or living with a partner), or becoming a parent, have an impact on social roles, relationships and choices for the future [23]. Expressed in years, medical students have a rather long period of study and preparation before they start a career as medical specialist. In the last years of their life as a student, some transitions in their stage of life might take place, such as having a partner or even a child. These experiences can influence the choice of a specialism, because ideas of a partner or responsibilities towards family life, can direct the specialty choice.

Furthermore, these students are confronted with conflicting roles. Being a student and partner can limit their preferences towards less challenging specialties [24]. We expect medical students living together with a partner will make other, family-friendly, specialty choices.

Also, we expect junior students to choose more idealistic options, perhaps the most appealing specialties, as opposed to older students who may choose more realistic options that is specialties matching their other roles such as partners or parents.

\section{Motivational perspective}

Men and women do not only differ in their preference for a specialty, but also in the motives for their choice $[3,9,13,18,25,26]$. Generally, male students are more motivated by salary, status and the opportunity to implement technical activities. Female candidates are motivated by humanist and altruistic reasons [19,25,27]. Theoretically, intrinsic motivation is based more on personal involvement with the content of the work and external is based more on involvement with techniques and innovation [28]. Intrinsic motivation is related more to specialties in which patient-related activities make up a major component. This is mostly preferred by women. External motivation is related to specialties characterized by technical skills and physical exertion, which are more attractive for male students [9]. We expect male students to be more externally motivated, focused on salary and status and, within the specialty, on applying technical skills. Whereas the motives of female students will be more intrinsically focused on specialties with options for intensive patient contacts. 
Specific characteristics of several specialty choices seem to match with different types of motives. Intrinsic motives are related to personal and continuous care, such as relationships in GP practices. Specialties related to surgery seem to be more related to external motives, such as status and income and a high workload $[1,4,29]$. These relationships imply that motives could have a mediating role between gender and specialty choice.

It seems that the stage of life, and specific experiences, such as becoming involved in a permanent relationship, has an impact on motives, which consequently influences specialty choice [4]. Therefore, it can be expected that the stage of life is not only directly related to specialty choice, but mediated by motives.

\section{Summarizing: the conceptual model}

The conceptual model will give an insight into the choice of specialty of medical students which assumes several influences related to gender and the stage of life. In the model specialty choice will be divided into: (1) the choice of medical specialties or general practice and (2) the preference within medical specialties, divided into surgery or non-surgery specialties.

After medical students have finished their basic medical training most of them (85\%-90\%) continue their education with a specialist training [8]. In Figure 1 the time plan of several medical studies is given, which also gives an insight into at what point choices are made.

The first choice in further training is between training for general practice or for a medical specialty. On average, male students choose, more often than women $(63 \%$ against 57\%), a medical specialty [8].

A second choice is focused on all medical specialty training programmes. In the Netherlands, women are under-represented in surgery-related specialties, $10 \%$ of women against $90 \%$ men [20,30]. A GP training is generally chosen by $20 \%$ of the medical student population and women tend to choose the option more often. But, since the female population among medical students is growing, the number of women with a preference for a medical specialty is also increasing [30]. Despite recent changes in the overall population of medical students we still expect that male students will choose, more often, to train for medical specialties, and especially surgery-related specialties. GP training will be chosen by women more than by men.

In the conceptual model it is expected that a direct relationship exists between gender and the stage of life on the one hand, and the choice of specialty on the other hand. Beside this direct relationship, gender and stage of life are expected to relate to the motives of students in making their choices. The motivation of students is subdivided into: (1) Extrinsic motivation which is related to their profession and made up of aspects such as technical skills, status, and income, and; (2) Extrinsic motivation which is related to life-style including aspects such as working hours, controllable life-style, and having children, and finally; (3) Intrinsic motivation, which is related to personal involvement and patient-related activities. A partial mediating influence of motives is expected on the relationship between gender and the stage of life on the one hand and specialty choice on the other hand.

\section{Methods}

\section{Participants}

A questionnaire concerning the career preferences of medical students was used. The questionnaire was sent by e-mail to all student members of the KNMG (Royal Dutch Medical Association).

The response was 58\% $(\mathrm{N}=2397)$. Only 1478 students had filled in the questionnaire sufficiently for the

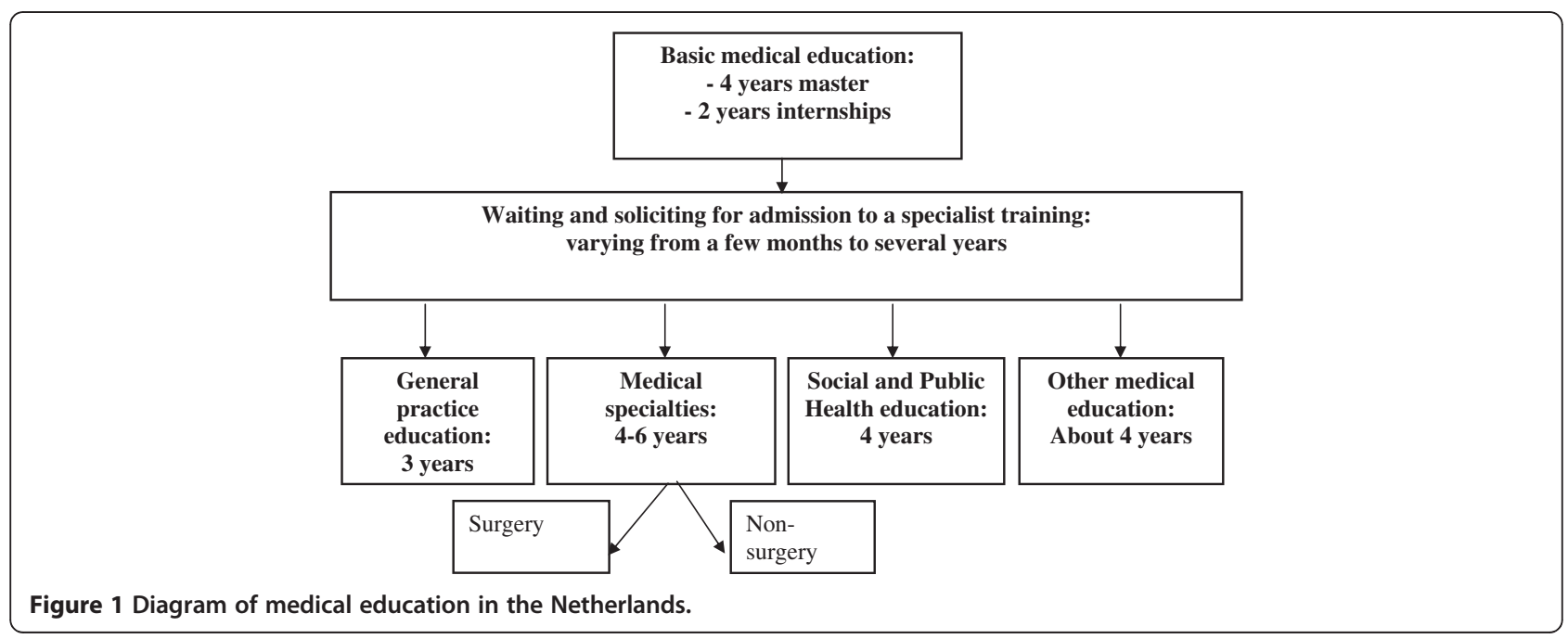


analyses, which is $36 \%$ of the population. This response group can be considered representative for the research population, since the comparison of demographic characteristics showed only a slight over-representation of female students (72\% against $68 \%$ ).

\section{Variables}

\section{Independent variables}

Gender was measured by the variable sex: $0=$ male, $1=$ female. Stage of life has been constructed by measuring two variables. In the first place the variable living together is divided into two levels: $0=$ 'not living together', $1=$ 'living together'. Living together was measured by being married or living with a partner. The second variable constructing the stage of life is educational stage. Two stages of basic medical training are constructed. In the first stage students are included who have studied for three years and gained between 0 and 180 credits the maximum in the Dutch system over three years. In the second stage students are included who studied more than three years and had more than 180 credits. The first stage is scored as 0 and the second stage $=1$.

\section{Dependent variables}

Choice of continuing medical education was divided into two preferences: medical specialty and general practice and the category: 'do not know'. For the analysis the variable of continuation choice is binary measured with $0=$ medical specialty and $1=$ general practice .

Medical specialism preference Students could indicate their preference for a type of medical specialty within five main categories, which are very common in the Dutch medical profession system: supportive, surgery and internal medicine as hospital oriented and psychiatry and ophthalmology as both hospital and/or solo practice and a sixth category of 'others' was added. For all hospital oriented categories and the 'other'-category students could further fill in their self-defined very specific specialist preference. These string variables resulted in a very long list of possible medical specialties. In order to have substantial numbers of students on different preferences we divided into specialties for which surgery skills are required and those requiring no surgery skills. The variable medical specialty preference has two categories $0=$ non-surgery specialty, $1=$ surgery specialty.

\section{Mediating variables}

Motivation Respondents could choose among 15 motives which could support specialty choice. On a fivepoint scale, the importance of each motive could be indicated. To retrieve clusters of motives, factor analysis was applied (table 1). It provided three factors on: 1 .
Life-style characteristics (with the items 'domestic situation', 'control of life-style,' 'having small children', 'flexible working hours'); 2 . Profession-related characteristics (with the items 'high status', 'favourable circumstances at work', 'high income' and 'career and promotion expectancies'); and 3. Personal involvement (with the items 'interest in the field', 'patient oriented and meaningful', 'internal motivation' such as 'achieving happiness' and the 'contents of the future profession'). Three items were not loading on one of the factors: 'the opportunity of rotation in the field of subspecialty', 'learning special skills' and 'availability of training'. These items are not used in analyses. In addendum 1 the motivation items are presented.

\section{Analyses}

\section{Mediation analyses}

It is expected that the relationship between gender and the stage of life on the one hand, and the choice of continuation and specialty choice on the other hand, is mediated by the motives supporting the choice. The following set of regression analyses are performed separately for both the independent variables: continuation choice and medical specialty choice [31]. These are: (1) a binary logistic regression of gender and the stage of life

\begin{tabular}{|c|c|c|c|c|}
\hline \multirow[t]{2}{*}{ Factor } & \multirow[t]{2}{*}{ Items } & \multicolumn{3}{|c|}{ Factor loadings } \\
\hline & & 1 & 2 & 3 \\
\hline \multirow{4}{*}{$\begin{array}{l}\text { Life-style } \\
\text { characteristics } \\
\text { (external) }\end{array}$} & Domestic situation & 0.89 & & \\
\hline & Having small children & 0.88 & & \\
\hline & Control on life-style & 0.82 & & \\
\hline & Flexible working hours & 0.81 & & \\
\hline $\begin{array}{l}\text { Profession-related } \\
\text { characteristics }\end{array}$ & Status & & 0.87 & \\
\hline \multirow[t]{3}{*}{ (external) } & $\begin{array}{l}\text { Favourable } \\
\text { circumstances at work }\end{array}$ & & 0.82 & \\
\hline & Income & & 0.77 & \\
\hline & $\begin{array}{l}\text { Careers and } \\
\text { promotion expectancies }\end{array}$ & & 0.73 & \\
\hline Personal involvement & Interest in the field & & & 0.80 \\
\hline \multirow[t]{3}{*}{ (intrinsic) } & $\begin{array}{l}\text { Patient-oriented } \\
\text { and meaningful }\end{array}$ & & & 0.78 \\
\hline & $\begin{array}{l}\text { Internal motivation } \\
\text { such as achieving } \\
\text { happiness }\end{array}$ & & & 0.70 \\
\hline & $\begin{array}{l}\text { Contents of the } \\
\text { future profession }\end{array}$ & & & 0.63 \\
\hline $\mathrm{R}^{2}$ & 0.64 & & & \\
\hline
\end{tabular}


conditions (living together and stage of education) on the choice; (2) with multiple regression the relationship between gender and the stage of life conditions on the one hand and the mediator variables (motives) on the other hand are examined; (3) a binary logistic regression on the relationship between mediator and the choice is performed; and (4) a binary logistic regression of gender, stage of life conditions and the mediator on the preferred choice. Logistic regressions are performed in four steps to meet the expectations we hypothesized in the theoretical background.

All mediating steps are separately analysed for students in the first and the second stage of education because we expect some cohort effects related to the stronger influence of the stage of life in the second stage. In all analyses, we controlled whether gender was a moderator for living together and for the stage of education, but these interactions were not found.

\section{Factor analysis}

For stipulating the motives that played a role in the choice of a specialty, principal components factor analyses have been carried out on the question concerning the importance of mentioned motives for the choice of a specialty. Varimax Rotatione with Kaiser normalization is used [32]. Only the items with a factor contribution of 0.40 or higher on 1 factor, but which have contributed low on the remaining factors, are included.

Three factors were traced and they explain together $64 \%$ of the total variance. Factor 1 concerns external motivation on life-style characteristics with four items mentioned in table 1 .

(Cronbach's Alpha $=.89$ ). Also factor 2 is external in nature, focused on professional characteristics (4 items, Cronbach's Alpha $=.82)$. The third factor constitutes personal involvement (4 items, Cronbach's Alpha $=.74$ ).

\section{Results}

The correlations between gender, the stage of education, living together, the motives and specialty choice are given in table 2 . These results are in line with outcomes of earlier studies $[3,8,9,19,25,27,33]$.

The characteristics of the population are given in table 3. As expected, students in the second stage of education are older and are more often living with a partner. From a considerable number of students their stage was unknown. On average their age is comparable to the age of students in the second stage.

The percentage of men and women living together is not very different in each stage of education, but in the population of which their stage is unknown relatively more women than men are living together.

Relatively more students in the second and in the unknown stage made a choice for continuing medical education as well as for a medical specialty compared to students in the first stage. Almost $30 \%$ of first stage students does not know what choice they will make and for second stage students this is $14 \%$. From those who chose medical specialty almost 19\% of the first stage students and $14 \%$ of the second stage students could not make a choice yet between surgery or non-surgery.

\section{Gender, choice and motivation}

The choice of continuing medical education between medical specialties or general practice is, as expected, influenced by gender (see Model 1, Table 4). Compared to women, men are less likely to prefer general practice to medical specialty. However in separate analyses for the stage of education this 'gendered' impact was not found.

In their preference for a medical specialty men choose less often a non-surgery specialty as opposed to a surgery specialty compared to women (Model 3 in Table 5). For students in the first stage this preference in medical specialty was not found.

Gender differences in motives are found in table 6. It shows that gender contributes to profession-related motives and motives related to life-style for specialty preferences. Men value profession-related motives higher, whereas women value life-style motives higher than men.

Table 2 Means, standard deviations and Pearson correlations of all variables

\begin{tabular}{|c|c|c|c|c|c|c|c|c|c|c|}
\hline & & $\mathbf{M}$ & SD & 1 & 2 & 3 & 4 & 5 & 6 & 7 \\
\hline 1 & Gender & & & & & & & & & \\
\hline 2 & Stage of education & & & .03 & & & & & & \\
\hline 3 & Living together & & & .05 & $20^{* *}$ & & & & & \\
\hline 4 & Choice of continuing medical education & & & $.10^{* *}$ & .01 & $.12^{* *}$ & & & & \\
\hline 5 & Medical Specialty preference & & & $-.10^{* *}$ & -.08 & $-.14^{* *}$ & .00 & & & \\
\hline 6 & Life-style characteristics- external motivation & 3.61 & .86 & $.18^{* *}$ & .06 & $.13^{* *}$ & $.26^{* *}$ & $-.11^{* *}$ & & \\
\hline 7 & Professional characteristics - external motivation & 3.35 & .77 & $-.19^{* *}$ & $-.06^{*}$ & -.02 & $-.19^{* *}$ & $.18^{* *}$ & $.15^{* *}$ & \\
\hline 8 & Personal involvement - intrinsic motivation & 4.33 & 60 & $.08^{* *}$ & $.15^{* *}$ & $.07^{* *}$ & $.09^{* *}$ & -.06 & $.22^{* *}$ & $.11^{* *}$ \\
\hline
\end{tabular}


Table 3 Characteristics of all respondents $(\mathrm{N}=1478)$, respondents of the first stage of education $(\mathrm{N}=679)$ and the second stage of education $(\mathrm{N}=396)$

\begin{tabular}{|c|c|c|c|c|}
\hline Characteristics & $\begin{array}{l}\text { All } \\
\text { respondents }\end{array}$ & $\begin{array}{l}\text { Respondents first } \\
\text { education stage }\end{array}$ & $\begin{array}{l}\text { Respondents second } \\
\text { education stage }\end{array}$ & $\begin{array}{l}\text { Respondents unknown } \\
\text { education stage }\end{array}$ \\
\hline Average age & 22.8 & 20.6 & 23.9 & 23.8 \\
\hline Gender: men & $27.8 \%$ & $28.3 \%(N=192)$ & $26.0 \%(N=103)$ & $28.8 \%(N=116)$ \\
\hline women & $72.1 \%$ & $71.7 \%(\mathrm{~N}=487)$ & $74.0 \%(\mathrm{~N}=293)$ & $71.0 \%(\mathrm{~N}=286)$ \\
\hline Living together: men & $16.5 \%(N=67)$ & $8.9 \%(N=17)$ & $23.3 \%(N=24)$ & $6.5 \%(N=26)$ \\
\hline women & $20.6 \%(N=220)$ & $12.3 \%(\mathrm{~N}=60)$ & $28.3 \%(N=83)$ & $19.1 \%(\mathrm{~N}=77)$ \\
\hline Stage of education: first stage & $45.9 \%(N=679)$ & & & \\
\hline second stage & $26.8 \%(N=396)$ & & & \\
\hline unknown & $27.3 \%(N=403)$ & & & \\
\hline \multicolumn{5}{|c|}{ Choice of continuing medical education: } \\
\hline General practice & $9.7 \%(N=144)$ & $8.2 \%(\mathrm{~N}=56)$ & $10.1 \%(N=40)$ & $11.9 \%(N=48)$ \\
\hline Medical specialty & $61.9 \%(N=915)$ & $57.4 \%(N=390)$ & $67.2 \%(N=266)$ & $64.3 \%(N=259)$ \\
\hline do not know & $21.6(N=319)$ & $29.2 \%(N=198)$ & $14,1 \%(N=56)$ & $16.1 \%(\mathrm{~N}=65)$ \\
\hline other & $5.7 \%(\mathrm{~N}=84)$ & $3.5 \%(N=24)$ & $7,9 \%(N=31)$ & $5,2 \%(N=21)$ \\
\hline missing & $1.0 \%(\mathrm{~N}=16)$ & $0.4 \%(N=3)$ & $0.8 \%(N=3)$ & $2,5 \%(N=10)$ \\
\hline \multicolumn{5}{|l|}{ Medical specialty choice: } \\
\hline Surgery specialty & $21.5 \%(N=318)$ & $20.2 \%(N=137)$ & $23.7 \%(N=94)$ & $21.6 \%(N=87)$ \\
\hline Non-surgery specialty & $25.2 \%(N=373)$ & $19.4 \%(N=132)$ & $31.1 \%(N=123)$ & $29.3 \%(N=118)$ \\
\hline others & $17 \% \%(N=148)$ & $18.7 \%(N=73)$ & $13.9 \%(\mathrm{~N}=37)$ & $14.7 \%(\mathrm{~N}=38)$ \\
\hline missing & $3.0 \%)(\mathrm{N}=32)$ & $5.4 \%(\mathrm{~N}=21)$ & $1.6 \%(N=4)$ & $2.7 \%(N=7)$ \\
\hline
\end{tabular}

Stage of life, choice and motivation

The influence of the stage of education on the choice of continuing medical education (Model 1, Table 4) and on medical specialty preference (Model 4, Table 4) has not been found.

Living together with a partner influences the choice of continuing medical education (Model 1, Table 4). Medical students living together with a partner are more likely to prefer general practice to a medical specialty, compared to students who are not living with a partner. This was also found for students in both stages of education.

Furthermore, medical students who are living with a partner are less likely to prefer a surgery specialty than a non-surgery specialty, compared to medical students who are not living with a partner (Model 3, Table 5). This difference was not found for students in both stages separately.

The regression analysis (Table 6) shows that whether or not living with a partner is not related to profession-bound motives, but it has a significant effect on life-style motivation. Medical students who are living together with a partner are more focused on life-style motives than those who are not living with a partner. Separate analyses showed that these results only hold for students in the second stage.

\section{Testing the model}

Tables 4 and 5 show the results of binary logistic regression analysis. The models concerning all students have respectively $86.9 \%, 87.4 \%, 57.8 \%$ and $58.6 \%$ of the variables correctly allocated. The percentages of Model 3 and Model 4 can be characterized as relatively low, but they are still capable of being interpreted. The same characteristics were found for separate analyses for both stages of education. The Chi-square tests show that all models fit the data sufficiently. The proportion of explained variance $\left(\mathrm{R}^{2}\right)$ for Models 1 to 4 was successively $3 \%, 23 \%, 5 \%$ and $10 \%$ for the whole population. The proportions for the explained variance of separate analyses for students in both stages were in the same range.

The choice of continuing medical education (Model 1, Table 4) is mainly explained by the variable living together with a partner, followed by the contribution of gender. Women living together with a partner are more likely to choose general practice. In separate analyses for both stages of education, the gender impact was not found. Only students living together with a partner are more likely to prefer general practice.

Regarding the mediating effects of motives, it is found that the choice of continuing medical education is largely influenced by life-style motives (Model 2, table 4). Life-style factors such as flexible working hours and having small children are related to the choice of general practice above medical specialties. Furthermore, intrinsic motives such as personal involvement are related to the 
Table 4 Logistic Regression on Choice of continuing medical education ${ }^{1}$ for all students, first stage students and second stage students (B-values, Odds Ratio, Wald statistics)

\begin{tabular}{|c|c|c|c|c|c|c|c|c|c|c|c|c|c|c|c|c|c|c|}
\hline & \multicolumn{6}{|c|}{ All $(\mathrm{N}=699)$} & \multicolumn{6}{|c|}{ First stage $(\mathrm{N}=408)$} & \multicolumn{6}{|c|}{ Second stage $(\mathrm{N}=291)$} \\
\hline & \multicolumn{3}{|c|}{ Model 1} & \multicolumn{3}{|c|}{ Model 2} & \multicolumn{3}{|c|}{ Model 1} & \multicolumn{3}{|c|}{ Model 2} & \multicolumn{3}{|c|}{ Model 1} & \multicolumn{3}{|c|}{ Model 2} \\
\hline & $B$ & $\operatorname{Exp}(B)$ & Wald & $B$ & $\operatorname{Exp}(B)$ & Wald & $B$ & $\operatorname{Exp}(B)$ & Wald & $B$ & $\operatorname{Exp}(B)$ & Wald & $B$ & $\operatorname{Exp}(B)$ & Wald & $B$ & $\operatorname{Exp}(B)$ & Wald \\
\hline Gender 2,5 & 0.55 & 1.74 & $4.09 * \mathbf{a}$ & -0.02 & 0.98 & 0.00 & 0.46 & 1.58 & 1.70 & 0.00 & 1.00 & 0.00 & 0.72 & 2.04 & 2.63 & 0.04 & 1.04 & 0.007 \\
\hline Stage of education ${ }^{3}$ & -0.02 & 0.99 & 0.00 & -0.14 & 0.87 & 0.31 & & & & & & & & & & & & \\
\hline Living together 4,5 & 0.67 & 1.95 & $6.69^{*}$ & 0.27 & 1.30 & 0.84 & 0.74 & 2.09 & $4.01^{*}$ & 0.64 & 1.90 & 2.63 & 0.71 & 2.04 & $4.00^{*}$ & 0.35 & 1.42 & 0.83 \\
\hline $\begin{array}{l}\text { Profession-related } \\
\text { motives (external) }\end{array}$ & & & & -1.06 & 0.35 & $38.12^{* * *}$ & & & & -0.21 & 0.81 & 1.33 & & & & -0.70 & 0.50 & $9.18^{* *}$ \\
\hline $\begin{array}{l}\text { Life-style motives } \\
\text { (external) }\end{array}$ & & & & 1.18 & 3.24 & $41.52^{* * *}$ & & & & 0.91 & 2.48 & $15.37^{* *}$ & & & & 0.97 & 2.63 & $13.39^{* * *}$ \\
\hline $\begin{array}{l}\text { Personal involvement } \\
\text { (intrinsic) }\end{array}$ & & & & 0.64 & 1.90 & $6.81^{* *}$ & & & & 0.79 & 2.20 & $5.12^{*}$ & & & & 0.64 & 1.90 & 3.16 \\
\hline Nagelkerke Pseudo $R^{2}$ & 0.03 & & & 0.23 & & & 0.03 & & & 0.15 & & & 0.043 & & & 0.19 & & \\
\hline $\begin{array}{l}\mathrm{Chi}^{2}(\mathrm{df}=3 \& d f=6) /{ }^{b} \\
\mathrm{Chi}^{2}(\mathrm{df}=2 \& d f=5)\end{array}$ & $11.37^{* *}$ & & & $93.40^{* * *}$ & & & ${ }^{b} 5.67$ & & & $b_{33.75^{* * *}}$ & & & ${ }^{b} 7.02^{*}$ & & & $b_{32.02 * * *}$ & & \\
\hline
\end{tabular}

${ }^{*} p<0.05 ; * * 0<0.01 ; * * * 0.001$.

$\mathrm{a}=0.046$

${ }^{1}$ medical specialty $=0$; general practice $=1 ;{ }^{2} 0=$ male; $1=$ female; ${ }^{3}$ first stage $=0$; second stage $=1 ;{ }^{4} 0=$ not living together; $1=$ living together.

${ }^{5}$ Controlled for gender $\mathrm{x}$ living together: $p>.05$. 
Table 5 Logistic regression on Preference for Medical specialty ${ }^{\mathbf{1}}$ for all students, first stage students and second stage students (B-values, Odds Ratio,

Wald statistics)

\begin{tabular}{|c|c|c|c|c|c|c|c|c|c|c|c|c|c|c|c|c|c|c|}
\hline & \multicolumn{6}{|c|}{ All $(\mathrm{N}=462)$} & \multicolumn{6}{|c|}{ First stage $(\mathrm{N}=253)$} & \multicolumn{6}{|c|}{ Second stage $(\mathrm{N}=209)$} \\
\hline & \multicolumn{3}{|c|}{ Model 3} & \multicolumn{3}{|c|}{ Model 4} & \multicolumn{3}{|c|}{ Model 3} & \multicolumn{3}{|c|}{ Model 4} & \multicolumn{3}{|c|}{ Model 3} & \multicolumn{3}{|c|}{ Model 4} \\
\hline & $B$ & $\operatorname{Exp}(B)$ & Wald & $B$ & $\operatorname{Exp}(B)$ & Wald & $B$ & $\operatorname{Exp}(B)$ & Wald & $B$ & $\operatorname{Exp}(B)$ & Wald & $B$ & $\operatorname{Exp}(B)$ & Wald & $B$ & $\operatorname{Exp}(B)$ & Wald \\
\hline Gender 2,5 & -0.57 & 0.57 & $7.98^{* *}$ & -0.32 & 0.72 & 2.29 & -0.52 & 0.60 & 3.77 & -0.33 & 0.72 & 1.42 & -0.60 & 2.04 & $3.87^{*}$ & -0.14 & 0.87 & 0.18 \\
\hline Education stage $^{3}$ & -0.28 & 0.76 & 2.08 & -0.18 & 0.83 & 0.85 & & & & & & & & & & & & \\
\hline Living together ${ }^{4,5}$ & -0.68 & 0.51 & $6.40^{*}$ & -0.59 & 0.55 & $4.65^{*}$ & -0.72 & 0.49 & 3.25 & -0.70 & 0.50 & 3.00 & -0.52 & 2.04 & 2.11 & -0.27 & 0.76 & 0.49 \\
\hline $\begin{array}{l}\text { Profession related motives } \\
\text { (external) }\end{array}$ & & & & 0.48 & 1.62 & $12.09 * * *$ & & & & 0.37 & 1.45 & 3.78 & & & & 1.09 & 2.98 & $16.69^{* * *}$ \\
\hline Life-style motives (external) & & & & -0.26 & 0.77 & $4.50^{*}$ & & & & -0.20 & 0.82 & 1.48 & & & & -0.57 & 0.57 & $6.80^{* *}$ \\
\hline $\begin{array}{l}\text { Personal involvement } \\
\text { (intrinsic) }\end{array}$ & & & & -0.24 & 0.79 & 1.50 & & & & -0.15 & 0.87 & 0.39 & & & & 0.13 & 1.14 & 0.36 \\
\hline Nagelkerke Pseudo $\mathrm{R}^{2}$ & 0.05 & & & 0.10 & & & 0.04 & & & 0.07 & & & 0.04 & & & 0.17 & & \\
\hline $\begin{array}{l}C h i^{2}(d f=3 \& d f=6) /{ }^{a} \\
C h i^{2}(d f=2 \& d f=5)\end{array}$ & $18.92^{* * *}$ & & & $33.75^{* * *}$ & & & a $7.42^{*}$ & & & a $12.62^{*}$ & & & a $6.34^{*}$ & & & ${ }^{\mathrm{a}} 27.33^{* * *}$ & & \\
\hline
\end{tabular}

${ }^{*} p<0.05 ;{ }^{* *} p<0.01 ;{ }^{* * *} p<0.001$.

${ }^{1}$ no surgery specialty $=0$; surgery specialty $=1 ;{ }^{2} 0=$ male; $1=$ female; ${ }^{3}$ first stage $=0$; second stage $=1 ;{ }^{4} 0=$ not living together; $1=$ living together.

${ }^{5}$ Controlled for gender $\mathrm{x}$ living together: $p>\ldots .05$. 
Table 6 Multiple Regression analysis for gender, the stage of education and living together-related with profession-related motives and life-style motives for all students, first stage students and second stage students

\begin{tabular}{|c|c|c|c|c|c|c|c|c|c|c|c|c|}
\hline & \multicolumn{4}{|c|}{ All } & \multicolumn{4}{|c|}{ First stage $(\mathrm{N}=253)$} & \multicolumn{4}{|c|}{ Second stage $(\mathrm{N}=209)$} \\
\hline & \multicolumn{2}{|c|}{$\begin{array}{l}\text { Profession- related } \\
\text { motives }(\mathrm{N}=1014)\end{array}$} & \multicolumn{2}{|c|}{$\begin{array}{l}\text { Life-style } \\
\text { motives } \\
(\mathrm{N}=1024)\end{array}$} & \multicolumn{2}{|c|}{$\begin{array}{l}\text { Profession- related } \\
\text { motives }(\mathrm{N}=635)\end{array}$} & \multicolumn{2}{|c|}{$\begin{array}{l}\text { Life-style } \\
\text { motives } \\
(\mathrm{N}=644)\end{array}$} & \multicolumn{2}{|c|}{$\begin{array}{l}\text { Profession- related } \\
\text { motives }(\mathrm{N}=379)\end{array}$} & \multicolumn{2}{|c|}{$\begin{array}{l}\text { Life-style } \\
\text { motives } \\
(\mathrm{N}=380)\end{array}$} \\
\hline & $\bar{\beta}$ & $t$ & $\bar{\beta}$ & $t$ & $\bar{\beta}$ & $t$ & $\bar{\beta}$ & $t$ & $\bar{\beta}$ & $t$ & $\bar{\beta}$ & $t$ \\
\hline Gender 1,4 & -0.19 & $-6.07^{*}$ & 0.18 & $5.91^{* * *}$ & -0.21 & $4.83^{* * *}$ & 0.18 & $4.66^{* * *}$ & -0.20 & $-3.95^{* * *}$ & 0.18 & $3.70^{* * *}$ \\
\hline $\begin{array}{l}\text { Stage of } \\
\text { education }\end{array}$ & -0.05 & -1.73 & 0.03 & 1.07 & & & & & & & & \\
\hline Living together 3,4 & -0.01 & -0.24 & 0.13 & $4.15^{* * *}$ & -0.01 & 0.21 & 0.06 & 1.55 & -0.01 & -0.28 & 0.22 & $4.35^{* * *}$ \\
\hline$R^{2}$ & 0.039 & & 0.048 & & 0.036 & & 0.037 & & 0.040 & & 0.082 & \\
\hline$\Delta R^{2}$ & 0.036 & & 0.045 & & 0.033 & & 0.034 & & 0.035 & & 0.078 & \\
\hline
\end{tabular}

${ }^{*} p<0.05 ;{ }^{* *} p<0.01 ;{ }^{* * *} p<0.001$.

${ }^{1} 0=$ male; $1=$ female; ${ }^{2}$ first stage $=0$; second stage $=1 ;{ }^{3} 0=$ not living together; $1=$ living together.

${ }^{4}$ Controlled for gender $\mathrm{x}$ living together: $p>.05$.

preference for general practice, whereas profession-related motives such as status and high income are not related to the choice of general practice. The influence of life-style motives on the choice of general practice prevailed in analyses for both stages of education. But intrinsic motives that is personal involvement, was only related to the preference for general practice for first stage students. The second stage students' choice of general practice had no relationship with profession-related motives.

For both gender and living with a partner, all three types of motives are mediating the relationship with the choice of continuing medical education. This is because after adding motives in Model 2 the effect of both gender and living with a partner disappeared. In separate analyses for the stage of education only for living with a partner, are the two types of motives mediating the choice of general practice. In both stages life-style motives were mediating that relationship, but, in addition, in the first stage, personal involvement, and in second stage, profession related, motives mediated the choice.

Although the effect of Model 3 is small it can be stated that in the preference of medical specialty (surgery or non-surgery), living with a partner, again, is the most influential factor followed by gender. Men without a partner prefer surgery specialties. For second stage students only gender influence was traced, saying that men prefer surgery specialties. For first stage students no influences for specialty preferences were found.

Considering the influence of motives profession-related motives and life-style motives determine the preferences. Profession-related motives such as status and high income and a low interest in life-style motives, such as flexible working hours, are both related to the preference for surgery specialties. These influences only hold for second stage students.

For gender both types of external motives, professionrelated and life-style, are mediating the relationship with medical specialty preference and this was also found for second stage students. Men with a preference for surgery specialties are influenced by profession-related motives and not by life-style motives.

In the whole population the influence of living with a partner was not mediated by motives.

\section{Discussion}

\section{Gender}

The finding that men aspire more to surgery specialties and women prefer more often general practice and nonsurgery specialties is consistent with previous research $[3,6,8-14]$. However, the significance of gender influence, stating the higher aspirations of women for general practice is not very strong (see table 4, Model 1: $\mathrm{p}=0.046$ ). In separate analyses of different stages of education this gender influence even disappeared.

Another finding was that no interaction effect was found between gender and living with a partner. Living with a partner seems to influence both male and female students in their preferences. These findings indicate that differences between male and female students in basic preferences are diminishing and family arguments are no longer only a female issue.

Students living with a partner may have other priorities, because they may be influenced by the ideas and expectations of their partner. This assumption is supported by the findings of Barshes et al. [29] showing that in case of a partner who does not support their career ambitions, married students prefer primary care above medical specialties. In addition, various studies show that married doctors often prefer general practice above a medical specialty, because of the higher compatibility with family life $[1,3,4,8,29]$. Future, research could focus in more detail on the role of the partner in the process of career choice. 


\section{Motives}

In types of motives men and women are differently oriented. Our results are consistent with findings stating that men are primarily motivated by income, status and technical aspects of work, while women are primarily motivated by life-style motives such as flexible working hours, and control over their life-style and domestic situation [9,25,27]. Surgery specialties are definitely dominated by men $[9,30,34,35]$. If living with a partner is as important for men as it is for women the coming generation of doctors will be more open-minded and support a cultural change in which surgery specialties are more accessible to women. Not all medical specialties facilitate the balance between home and work $[1,36]$. This situation may limit students with a partner in their choices, raising the possibility that they reconsider their initial choice and opt for a medical specialty more appropriate to their circumstances. Restricting medical students in their career choice because of the high demands in working conditions can be a negative strategy, which neglects talent and competencies [29,37].

Another issue is that motives are mediating the relationship between living with a partner and the choice of GP or medical specialty. Most students with a partner choose general practice, because it is more compatible with family life than a medical specialty [3,8,38]. For more clarity in the mediating effect of motives, longitudinal studies are necessary to find out to what extent motives change once someone has started to live together with a partner.

\section{Remarks and further research}

Firstly, since medical specialties differ considerable in professional characteristics [39], in future research more detailed analyses of each individual specialty could show clear distinctions between various motives and their relationship to each specialty separately.

Secondly, this study is focused on basic medical education. Future studies should at least include students who are in specialist training, because the number of students living with a partner is rather small in this study $[36,40]$.

Thirdly, this research has only focused on the needs and choices of respondents regarding their future careers. There are no data on the actual decisions they have taken or will take. For a better understanding of the choice process during medical education and employment, a cohort study on this subject is recommended. A fourth remark is about the factor analysis, which showed two different types of external motivation: professional and life-style oriented. This distinction was acceptable, because the content of the items were clearly focused on two domains (see addendum 1).

Finally, the present study provides a contribution to the existing knowledge of career aspirations of medical students. The research is innovative in that it focuses on the mediating effects of motivation on the relationship between gender and the stage of life on the one hand, and two types of choice in further medical career on the other hand. Moreover, this study highlights the differences between students who are living with a partner and those who are not. An interesting finding is the gender similarity in considering the family position as an important issue in medical preferences. The results establish a broader framework for the factors that are important in the selection process of medical students and therefore stimulate further research on this topic. In addition, given the fact that this investigation was aimed at medical students from all Dutch universities, the results can serve as a starting point for considerations in national policy.

\section{Conclusions}

From the perspectives of gender, the stage of education and whether living, or not, with a partner, this study has provided insight into the influence on choices in medical education, especially the impact of several types of motivation. For all respondents, the results show that gender and living with a partner influence the choices for a continuation in GP or medical specialty training, next to the preferences in medical specialty. Moreover, external and intrinsic motives are mediating, to a greater or lesser degree, this relationship. In all analyses no interactions were found between gender and living with a partner, which means that considering living with a partner as an important influence in preferences is no longer specific female-related as it was in the past.

The results for first stage students show only influences on the choice of continuing medical education and no influences for preferences in medical specialty. For second stage students, the results show influences on both the choice of continuing medical education and specialty preferences.

\section{Addendum 1: Motivation items}

Please indicate below how important each reason for your choice of specialty has been?

(5-point Likert-scale: very important - important neutral - unimportant - very unimportant)

Interested in the field

Possibility of rotation in the field of subspecialty

Favorable circumstances at work

Learning special skills

High status

Career and promotion expectancies

High income

Domestic situation

Having small children

Control on life style 


\author{
Patient oriented and meaningful \\ Availability of training \\ Flexible working hours \\ Achieving happiness \\ Contents of the future profession
}

\section{Competing interests}

The authors declare that they have no competing interests.

\section{Authors' contributions}

$\mathrm{PH}$ performed the statistical analyses, drafted the manuscript and contributed to all other aspects of the study.

\section{Acknowledgements}

In this study, students of the Department of Psychology of Utrecht University participated in collecting data and primary analyses and a former colleague, Hetty van Emmerik contributed as a coach to these students.

The career centre of the KNMG (Royal Dutch Medical Association) has given us the e-mail addresses of all their student members.

Received: 20 May 2011 Accepted: 18 July 2012

Published: 23 August 2012

\section{References}

1. Heiligers PJM, Hingstman L: Career preferences and the work and family balance in medicine: gender differences among medical specialists. Social Science \& Medicine 2000, 50:1235-1246.

2. Maiorova T, Stevens F, Scherpbier A, Van der Velden L, Van der Zee J: Genderrelated differences in general practice preferences: longitudinal evidence from the Netherlands 1982-2001. Journal of Health Policy 2005, 72(1):74-79.

3. Soethout MBM: Career preference of medical students and career choice of recent graduates. Factors influencing the preference for a choice of $a$ medical specialty in general and in public health in particular. PhD thesis. VU University Amsterdam, Department of Health Sciences; 2007.

4. Lambert TW, Davidson JM, Evans J, Goldacre MJ: Doctors' reasons for rejecting initial choices of specialties as long-term careers. Medical education 2003, 37:312-318.

5. Mahoney R, Katona C, McParland M, Noble L, Livingston G: Shortage specialties: Changes in career intentions from medical student tot newly qualified doctor. Medical Teacher 2004, 26(7):650-654.

6. Morrison J: Influences before and during medical school on career choices. Medical Education 2004, 38:230-231.

7. Tsimtsiou Z, Kerasidou O, Efstathiou N, Papaharitou S, Hatzimouratidis K, Hatzichristou D: Medical students' attitudes toward patient-centred care:a longitudinal survey. Medical Education 2007, 41(2):146-153.

8. Lugtenberg M, Heiligers PJM, Hingstman L: Artsen en hun carrièrewensen: een literatuurverkenning (Physicians and their career preferences, a literature survey). Utrecht: NIVEL; 2005.

9. Du Moulin MFMT, Heymans RJHM, Noordenbos G: Genderfactoren in de keus voor opleiding tot medisch specialist. (Gender factors in the choice of a medical specialty). Nederlands Tijdschrift Geneeskunde 2000, 144(3):129-133.

10. Winants YHWM: Co-assistenschappen als inwijding in de medischeberoepscultuur: gender in de socialisatie tot arts (Internships as initiation in the medical culture: gender in socialization to become a doctor). Maastricht: Unimaas; 1999.

11. Morrison J: Career preferences in medicine for the 21st century. Medical Education 2006, 40:495-497.

12. Sobral DT: Influences on choice of surgery as a career: a study of consecutivecohorts in an medical school. Medical Education 2006, 40:522-529.

13. Vaglum P, Wiers-Jenssen J, Ekeberg O: Motivation for medical school: therelationship to gender and specialty preferences in an nationwide sample. MedicalEducation 1999, 33:236-242.

14. Ward AM, Kamien M, Lopez DG: Medical career choice and practicelocation: early factors predicting course completion, career choice and practice location. Medical Education 2004, 38:239-248.

15. Matsumoto D, Juang L: Culture and Psychology. Belmont: Wadsworth/ Thomson Learning; 2004

16. Eckes T, Trautner HM (Eds): The developmental social psychology of gender. Mahwah, NJ: Lawrence Erlbaum; 2000
17. Van Emmerik IJH: Gender differences in the creation of different types of socialcapital: A multilevel study. Social Networks 2006, 28:24-37.

18. Offenbeek MAG, Kiewiet DJ, Oosterhuis MJ: The compatibility of future's doctors' career intentions with changing health care demands. Medical Education 2006, 40:530-538.

19. Maiorova T: The role of gender in medical specialty choice and general practice preferences. PhD thesis. Datawyse bv: Maastricht University, Department of Health Sciences; 2009.

20. Van der Velden LFJ, Hingstman L, Heiligers PJM, Hansen J: Toenemend percentage vrouwen in de geneeskunde: verleden, heden en toekomst. (Increasing proportion of women in medicine: past, present and future). Nederlands Tijdschrift voor Geneeskunde 2008, 152(40):2165-2171.

21. Nieman LZ, Gracely EJ: Where nontradition is the norm: are sex and age determinants of practicing primary care specialties? Journal of Women's Health \& Gender Based Medicine 1999, 8(7):967-972.

22. Crockett L: Agency in the life course: concepts and processes. Lincoln: University of Nebraska Press; 2002

23. Guichard J, Lenz J: Career Theory From an International Perspective. CareerDevelopment Quarterly 2005, 54(1):17-28.

24. Huang Q, Sverke M: Women's occupational career patterns over 27 years: relations to family of origin, life careers, and wellness. Journal of vocational behavior 2007, 70(2):369-379.

25. Clack GB, Head JO: Why do students want to study medicine? MedicalEducation 1997, 32:209-221.

26. Rademakers JJDJM Bloemen, ALS, Soethout MBM, Cohen-Schotanus J, ten Cate, ThJ: 2008). Verschillen in belangstellingsprofielen van vrouwelijke en mannelijke studenten geneeskunde (Differences in interest profiles of female and male medical students. Tijdschrift voor Medisch Onderwiis 2008, 27(4):171-180

27. Kruijthof CJ, Van Leeuwen CD, Ventevogel P, Van Der Horst HE, Van Staveren G: (1992). Career perspectives of women and men medical students. Medical Eduction 1992, 26:21-6.

28. Gedde SJ, Budenz DL, Haft P, Tielsch JM, Lee Y, Quigley HA: Factors influencing career choices among graduating ophthalmology residents. Journal of Ophthalmology 2005, 112(7):1250-1260.

29. Barshes NR, Vavra AK, Miller A, Brunicardi FC, Goss JA, Sweeney JF: General surgery as a career: a contemporary review of factors central to medical student specialty choice. Medical Education 2004, 199(5):792-799.

30. Sanders FBM: Loopbanen van vrouwelijke artsen (Careers of female physicians). Raad voor Volksgezondheid en Zorg (Council for Health and Health Care); 2005.

31. Baron RM, Kenny DA: The moderator-mediator variable distinction in social psychological research: conceptual, strategic and statistical considerations. Journal of Personality and Social Psychology 1986, 51:1173-1182.

32. Field AP: Discovering statistics using SPSS. London: Sage; 2005.

33. Nieuwhof MGH, Rademakers JJDJM, Kuyvenhoven MM, Soethout MBM, Ten Cate Th J: Students conceptions of the medical profession; an interview study. Medical Teacher 2005, 27(8):709-714.

34. Gjerberg E: (2002). Gender similiarities in doctors' preferences - and gender differences in final specialisation. Journal of Social Science \& Medicine 2002, 54(4):591-592. 599-601.

35. Meyboom-De Jong B: Emancipatie van de huisartsgeneeskunde (Emancipation of family medicine). Groningen: Afscheidscollege (Farewell lecture); 2004

36. Lugtenberg $\mathrm{M}$, Heiligers PJM, De Jong J, Hingstman L: Internal medicine specialists' attitudes towards working part-time: a comparison between 1996 and 2004. BMC Health Services Research 2006, 6:126-136.

37. Walker $\mathrm{CO}$, Greene BA, Mansell A: Identification with academics, intrinsic/ extrinsic motivation, and self-efficacy as predictors of cognitive engagement. Journal of Learning and Individual Differences 2006, 2006(16):3-5.

38. De Jong J, Heiligers $P$, Groenewegen PP, Hingstman L: Why are some medical specialists working part-time, while others work full-time? Health policy 2006, 78:235-248.

39. KNMG (Royal Dutch Society of Medicine): Het Medisch Profielen Boek: co-assistent en carrière (The medical Book of Profiles: interns and career). Zeist: GlaxoSmithKline; 2007.

40. Clarkberg M: R. Leasthaeghe. Meaning and choice: value orientations and the life course decision. NIDI/CBGS Publications; 2002.

doi:10.1186/1472-6920-12-82

Cite this article as: Heiligers: Gender differences in medical students' motives and career choice. BMC Medical Education 2012 12:82. 